\title{
Redescription of the snake Lachesis melanocephala (Squamata: Viperidae): Designation of a neotype, natural history, and conservation status
}

\author{
Alejandro Solórzano ${ }^{1 *} \&$ Mahmood Sasa ${ }^{2}$ \\ 1. Museo de Zoología, Universidad de Costa Rica, Ciudad Universitaria Rodrigo Facio, San Pedro de Montes de Oca, \\ San José, Costa Rica; solorzano29@gmail.com \\ 2. Instituto Clodomiro Picado y Escuela de Biología, Universidad de Costa Rica, Ciudad Universitaria Rodrigo Facio, \\ San Pedro de Montes de Oca, San José, Costa Rica; msasamarin@gmail.com \\ * Correspondance
}

Received 18-VI-2020. Corrected 18-VIII-2020. Accepted 11-IX-2020.

\begin{abstract}
Introduction: The Black-headed Bushmaster (Lachesis melanocephala) is a large venomous snake that inhabits tropical moist forest, wet forest, montane and premontane wet forest in Southwestern Costa Rica and extreme Western Panama. Objective: We assign a neotype for the species due to the loss of the original holotype and update the information on its geographical distribution, natural history, and conservation status. Methods: To determine the conservation status of L. melanocephala, we modeled its potential distribution using the species` locality records and distribution modeling analysis implemented in MaxEnt. Based on the species' potential distribution, we evaluate the loss of its original habitat and estimate the percentage of its distribution area that is currently protected by the country's protected area system. Results: The potential distribution of the species was estimated at $10139 \mathrm{~km}^{2}$, including areas where the species currently occurs and historical areas where the species has been registered but is nowadays considered locally extinct. About $29 \%$ of that potential distribution overlaps with protected wild areas, so less than a third of the potential distribution of the species is under protection. Conclusions: During the last decade, accelerated habitat loss and growing evidence of declining natural populations indicate the need for urgent protective measures to prevent the extinction of this species in the foreseeable future.
\end{abstract}

Key words: Neotropical pitvipers; snake conservation; species distribution model.

Solórzano, A., \& Sasa, M. (2020). Redescription of the snake Lachesis melanocephala (Squamata: Viperidae): Designation of a neotype, natural history, and conservation status. Revista de Biología Tropical, 68(4), 1384-1400.

The genus Lachesis (n.f., Daudin, 1803) represents a clade of Neotropical pitvipers that includes four nominal species distributed in the rainforest of South America and Isthmian Central America (Campbell \& Lamar, 2004; Wallach, Williams, \& Boundy, 2014). These are the longest venomous snakes in the Western Hemisphere and are considered the longest vipers in the world (Campbell \& Lamar, 2004). Besides their large size, species within Lachesis share several external characteristics that allow distinguishing them. In its distal part, the caudal region has small, bristling scales, even in the sub-tail area (Fernandes, 2001). The tail ends on a spine-shaped scale; some authors suggest it is involved in producing a warning sound when vibrates against the leaf litter (Ripa, 1994). The dorsal scales are warty, almost pyramidal, giving it a rough and warty appearance (the vernacular name assigned to bushmasters in Panamá and Colombia refers to that appearance). The dorsal coloration consists 
of a background of light brown, cream, or clay tones depending on the species and has a pattern of dark rhomboid designs that extends from the dorsal spine to the sides. These designs also vary interspecifically. The bushmaster species also share a unique feature among Neotropical pitvipers: they are oviparous, conceivably the only members of Viperidae that lay eggs in the New World (Campbell \& Lamar, 2004; see this same reference for a possible exception in Bothrocophias colombianus).

Among the bushmaster species, the Blackheaded Bushmaster (Lachesis melanocephala) is considered the most distinctive: the back of its head is heavily pigmented, forming a unique black cap (Fig. 1A, Fig. 1B, Fig. 1C). This characteristic makes this species locally known as Plato Negro (black plate), and the epithet "melanocephala" refers precisely to that dark coloration on the back of the head
(Solórzano \& Cerdas, 1986). The dorsal ground color is light, cream-white to yellowish, with rhomboidal markings that are dark gray or black (Fig. 1D). Lachesis melanocephala has the most restricted distribution, occurring in Southern and Southwestern Costa Rica (Savage, 2002; Solórzano, 2004; Sasa, Chaves, \& Porras, 2010). This species also occurs near the border with Costa Rica in Western Panama, in the Province of Chiriquí (Dwyer \& Perez, 2009, see below).

Populations currently assigned to L. melanocephala were first considered a synonymy of Lachesis muta (Daudin, 1803). In Costa Rica, early researchers did not distinguish between bushmaster populations at each side of the Cordillera Volcánica Central and the Talamanca mountain range, but they were aware of their presence (Picado, 1931; Taylor, 1954). Later, Vial \& Jiménez-Pórras (1966)

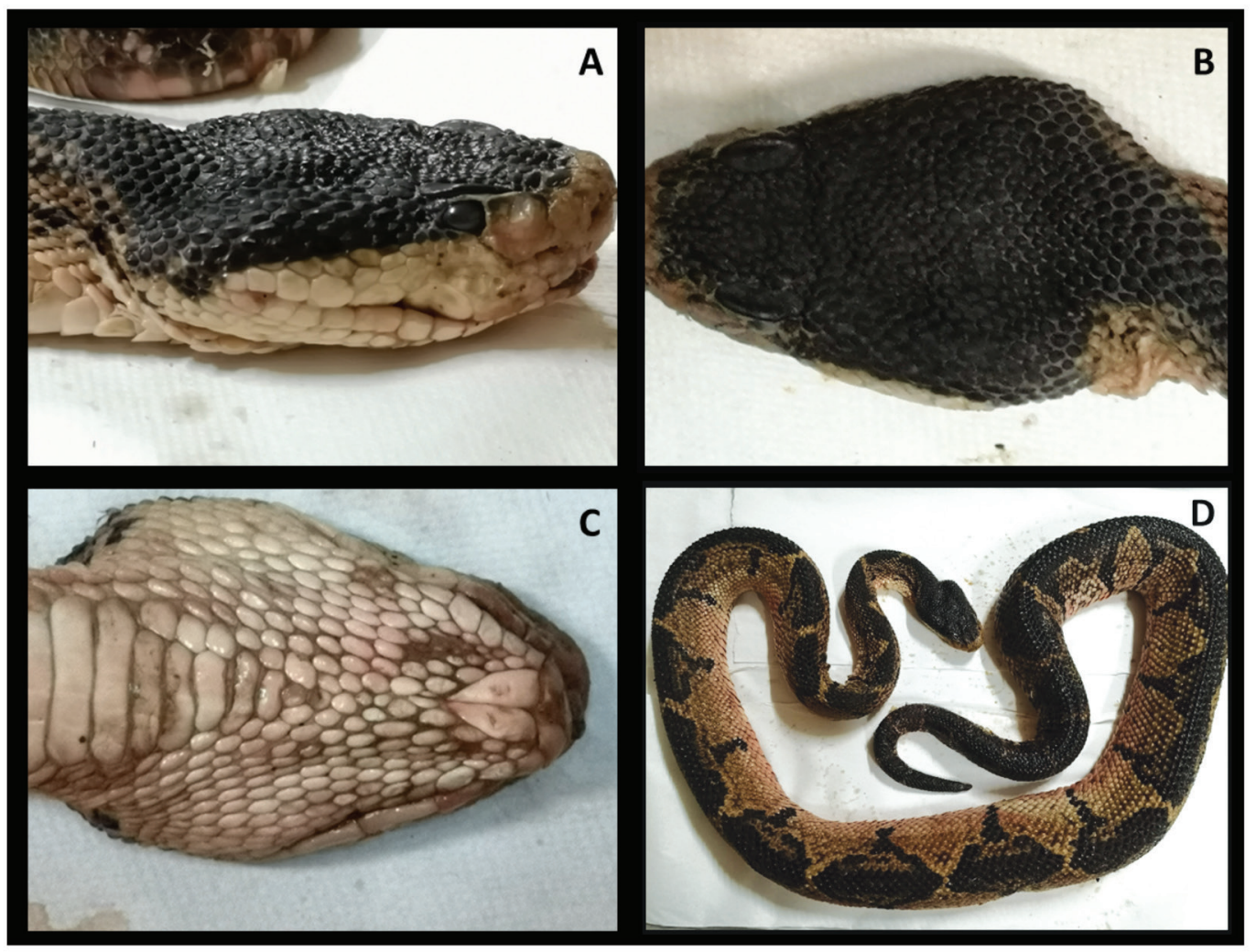

Fig. 1. Neotype of Lachesis melanocephala MZUCR-23185. A. Lateral view of head. B. Dorsal view of the head. C. Chin region. D. Full view. Note the dorsal body blotches. 
and Bolaños (1982) distinguished the Pacific and Caribbean forms, although they did not offer a formal taxonomic proposal. During those years, differences in venom characteristics between the Caribbean populations (= Lachesis stenophrys) and the South Pacific population were recognized by Roger Bolaños and collaborators at Instituto Clodomiro Picado (ICP), Universidad de Costa Rica (Bolaños, Muñoz, \& Cerdas, 1978).

Solórzano \& Cerdas (1986) first described Lachesis melanocephala as a subspecies of Lachesis muta. Besides their venom immunological differences, the authors found morphological evidence to support that Caribbean and Pacific bushmaster populations were distinct forms that warrant different taxonomic status. In the original description, the type series was collected from 1984 to 1986 in the Southern region of Puntarenas Province, Costa Rica. All specimens were deposited in the Museo Instituto Clodomiro Picado (MICP), a snake collection established in 1984 by one of us (ASL) at ICP in San José. The holotype MICP-301 was an adult male (1969 mm snout-vent length), collected $9 \mathrm{~km}$ Northern of Ciudad Neily. The paratypes localities were: MICP-302: Palmar Norte; MICP-303: Corcovado National Park on Península de Osa; MICP-304: Golfito; MICP-305: Palmar Sur; MICP-306: Sabalito de Coto Brus; MICP-307: Alturas del Río Cotón, East from Valle de Coto Brus (Solórzano \& Cerdas, 1986).

It would take another decade before the Black-headed Bushmaster was recognized as a full species. Ripa (1994) first suggested the convenience of elevating both L. melanocephala and L. stenophrys as valid species but did not take action on his proposal. Zamudio and Greene (1997) used mitochondrial gene sequences to reconstruct the phylogenetic relationships and historical biogeography of populations then assigned to Lachesis muta, including L. m. melanocephala, L. m. stenophrys, L. m. muta and L. m. rhombeata. Their results support a deep divergence between the Central and South American lineages, separated from 18 to 6 million years ago. These authors propose the species status for L. melanocephala and Lachesis stenophrys. Subsequently, Fernandes (2001) and Fernandes, Franco, \& Fernández (2004) confirm the Central American forms as valid species, separated from $L$. muta, from morphological characters related to squamation, hemipenes morphology, and coloration patterns.

The ICP museum collection was neglected during 1996-2000, resulting in the loss of many specimens during that period. One of the most painful losses was the holotype and paratypes of Lachesis melanocephala. These losses forced the cessation of maintaining the scientific collection at the Institute and the decision to send the remaining specimens to the Museum of Zoology, at the Universidad de Costa Rica (MZUCR).

Probably due to its relatively recent description and coupled with the fact that it is an uncommon species, the biology, and conservation status of $L$. melanocephala has not received much attention by the scientific mainstream (Solórzano, 2004). In fact, much of the information available on the ecology and behavior of this species comes from observations in captivity (see the section on Natural history, below).

In recent years, interest in this species has grown. Using ecological niche modeling, González-Maya, Castañeda, González, Pacheco, \& Ceballos (2014) estimated the extent of occupation for L. melanocephala in less than $10500 \mathrm{~km}^{2}$. According to these authors, the restricted distribution and high specificity to undisturbed habitats impose risky conditions for the survival of this species, suggesting that this situation coincides with the IUCN criteria for categorizing a species as Endangered (IUCN, 2012). So far, however, only $L$. muta rhombeata from the Atlantic of Brazil is listed by IUCN, as Vulnerable, whereas no other Bushmaster species is included in any other category.

The loss of forest cover throughout the distribution of $L$. melanocephala is significant (Garcia, Obando, \& Murillo, 2005), contributing to the notion that populations of this species 
are threatened and restricted to the few protected areas in the region (González-Maya et al., 2014). In fact, the establishment and maintenance of a network of protected areas is the most substantial conservation action that Costa Rica has taken to preserve its snake diversity, including the Bushmasters (Sasa et al., 2010). The protection of areas is carried out by the Sistema Nacional de Áreas de Conservación (SINAC, 2020), the state agency in charge of policies, planning, and execution of processes aimed at the sustainability of the country's natural resources. SINAC administrates the national parks and reserves and also regulates activities that involve the management of wild species. Conservation strategies based on protected areas assume that these areas represent the minimum amount of land that might remain for many wildlife species if current deforestation and urbanization patterns continue. However, it is not clear whether these protected areas are enough to support viable populations of L. melanocephala or if other conservation strategies should be implemented for its protection.

Based on the loss of the holotype (Solorzano \& Cerdas, 1986), herein, we provide a re-description of this species Lachesis melanocephala and assign a neotype. We also update the information on the geographic distribution and natural history of this species. In addition, we use species distribution modeling to assess the state reserves' role in the conservation of this species. To make this assessment, we tried to answer two specific questions: Is Costa Rica's protected area system enough to protect the Black-headed Bushmaster? Are these protected areas large enough to support viable populations of this species?

\section{MATERIALS AND METHODS}

Taxonomic and natural history account: We reviewed specimens of $L$. melanocephala deposited in the Museum of Zoology, Universidad de Costa Rica (MZUCR, http://museo. biologia.ucr.ac.cr/). Scutellation followed Fernandes et al. (2004). For the natural history account, we drew on our observations in the field or captivity from close to 15 specimens observed in more than 40 combined years of snake biology studies in Costa Rica. We complement our notes with information from published scientific references.

Potential distribution estimation: We gathered occurrence data for the Black-headed Bushmaster from locality records at MZUCR, the literature, and our field observations (Table 1). To estimate the potential distribution of L. melanocephala, we performed a species distribution model using the maximum entropy algorithm program MaxEnt (Phillips, Anderson, \& Schapire, 2006). MaxEnt is a presence-background approach that uses information from climatic conditions on occurrence datasets. This algorithm allows discriminating between suitable non-suitable areas by assigning a probability of occurrence for the study species (Phillips et al., 2006).

To generate the model, we used environmental data from 19 bioclimatic variables from WorldClim (2020). These layers described annual means of environmental conditions and were generated by land area interpolations of monthly precipitation and temperature data at weather stations worldwide from 1950 to 2000 (Hijmans, Cameron, Parra, Jones, \& Jarvis, 2005). For data extraction and model construction, we calibrated the model to the extent of Costa Rica by cropping the bioclimatic layers within a defined bounding box (7.750$11.500 \mathrm{~N}, 82.150-86.250 \mathrm{~W})$.

We developed the model with ENMeval (Muscarella et al., 2014). This package facilitates the construction and evaluation of MaxEntgenerated SDMs with tuned settings, therefore avoiding the selection of overfitted models. We generated a series of candidate models using linear, quadratic, hinge, product and threshold feature classes, and regularization multipliers ranging from 0.5 to 5 (with increases of 0.5 ), resulting in a total of 60 models. For data partition, we used the method "block." To select the most robust model, we used two metrics: 1) AUCTEST (AUC) to evaluate environmental 
TABLE 1

Localities records for the Black-headed Bushmaster (Lachesis melanocephala) in Southern and Southwestern Costa Rica

\begin{tabular}{|c|c|c|c|c|}
\hline Country & Locality & Latitud & Longitud & Elevation (m) \\
\hline CR & Tinamastes, Pérez Zeledón, San José & 9.3029 & -83.7953 & 700 \\
\hline $\mathrm{CR}$ & Dominical, Puntarenas & 9.2564 & -83.8551 & 122 \\
\hline $\mathrm{CR}$ & Uvita, Puntarenas & 9.2262 & -83.8267 & 153 \\
\hline $\mathrm{CR}$ & Buenos Aires, Puntarenas & 9.1717 & -83.3003 & 455 \\
\hline $\mathrm{CR}$ & Cajón Sur, Buenos Aires, Puntarenas & 8.9492 & -83.3406 & 298 \\
\hline $\mathrm{CR}$ & Curré, Buenos Aires, Puntarenas & 8.9904 & -83.2683 & 215 \\
\hline $\mathrm{CR}$ & Palmar Norte, Osa, Puntarenas & 8.9803 & -83.4594 & 368 \\
\hline $\mathrm{CR}$ & Los Mogos, Península de Osa & 8.7430 & -83.3200 & 179 \\
\hline $\mathrm{CR}$ & Rincón, Península de Osa & 8.7042 & -83.5044 & 181 \\
\hline $\mathrm{CR}$ & San Juan de Rincón, Península de Osa & 8.7659 & -83.4720 & 267 \\
\hline $\mathrm{CR}$ & Rancho Quemado, Península de Osa & 8.6918 & -83.5567 & 370 \\
\hline $\mathrm{CR}$ & Cerro Chocuaco, Rancho Quemado, Península de Osa & 8.7425 & -83.5611 & 549 \\
\hline $\mathrm{CR}$ & Dos Brazos de Río Tigre, Puerto Jiménez & 8.5334 & -83.4000 & 119 \\
\hline $\mathrm{CR}$ & La Palma, Puerto Jiménez, Península de Osa & 8.6588 & -83.4403 & 9 \\
\hline $\mathrm{CR}$ & Playa Blanca, Puerto Jiménez, Península de Osa & 8.6373 & -83.4399 & 11 \\
\hline $\mathrm{CR}$ & Los Patos, Parque Nac. Corcovado, Península de Osa & 8.5802 & -83.5046 & 215 \\
\hline $\mathrm{CR}$ & La Gamba, Golfito, Puntarenas & 8.6998 & -83.1864 & 122 \\
\hline $\mathrm{CR}$ & Piedras Blancas, Golfito, Puntarenas & 8.7835 & -83.2330 & 108 \\
\hline $\mathrm{CR}$ & Cerro Adams, Golfito, Puntarenas & 8.6487 & -83.1573 & 279 \\
\hline $\mathrm{CR}$ & Cerro Paraguas, Las Cruces, San Vito de Coto Brus & 8.4715 & -82.5916 & 1105 \\
\hline $\mathrm{CR}$ & Jardín Botánico Wilson, Las Cruces, San Vito de Coto Brus & 8.7889 & -82.9583 & 1150 \\
\hline $\mathrm{CR}$ & Sabalito, San Vito de Coto Brus, Puntarenas, & 8.8168 & -82.9132 & 946 \\
\hline $\mathrm{CR}$ & Alturas de Cotón, Puntarenas & 8.9500 & -82.8333 & 1227 \\
\hline $\mathrm{CR}$ & Las Tablas, Talamanca, Puntarenas & 8.9444 & -82.7528 & 1873 \\
\hline $\mathrm{CR}$ & Ciudad Neily, Corredores, Coto 47, Puntarenas & 8.6038 & -82.9672 & 152 \\
\hline $\mathrm{CR}$ & Villa Briceño & 8.7200 & -83.1639 & 90 \\
\hline $\mathrm{CR}$ & Ciudad Cortés & 8.9681 & -83.5233 & 20 \\
\hline Panamá & Chiriquí, Cantón Racimiento, Finca Hartmann & 8.84504 & -82.7607 & 1200 \\
\hline
\end{tabular}

discrimination and 2) minimum training present omission rate (ORMTP) to evaluate overfitting (Muscarella et al., 2014).

To estimate the geographic area occupied by the Black-headed Bushmaster, we transformed our prediction into a binary map to visualize the relative distribution of suitable and unsuitable conditions across Costa Rica. We employed a 10th percentile presence (Radosavljevic \& Anderson, 2014). This rigorous criterion sets the threshold value that it discards as "suitable habitat," the 10 percent of the localities predicted with the lowest suitability values. We found this threshold was appropriate after testing other more conservative limits that tend to over predict the geographic distributions.
Conservation assessment: To assess whether the protected areas system in Costa Rica is sufficient to keep populations of $L$. melanocephala, we followed two approaches. First, we evaluated the proportion of the species distribution area under some land protection category. We plotted the extent of occurrences of the Black-headed Bushmaster over the layers of forest types and SINAC protected areas; then, we estimated the proportion of area that lies under some protection category. The forest and protected areas layers were obtained from ATLAS Costa Rica of the Technological Institute of Costa Rica (Ortíz-Malavasi, 2014).

We also take a heuristic approach to investigate if the protected areas within the species distribution are capable of maintaining 
sustainable populations of Black-headed Bushmasters. Our approach takes advantage of the concept of Minimum Viable Populations (MVP), the smallest size that a population must have to persist (Gilpin \& Soule, 1986). This concept has been used as a useful framework to assess the risk of extinction in wildlife populations. Reed, O'Grady, Brook, Ballau, \& Frankham (2003) presented MVP for several reptiles and other vertebrates; their adjusted MVP mean $( \pm$ SD) estimated for large pitvipers is $13212( \pm 649)$ individuals. If we assume a similar MVP for bushmasters, we need to determine the minimum viable area (MVA) that will support them. Since we lack estimates of bushmaster density in their habitat, we used density estimates for Bothrops asper, the most common pitviper in humid environments in
Costa Rica. For this last species, mean density estimations are around 0.48 individuals/ hectare (Sasa, Wasko, \& Lamar, 2009). Densities for bushmasters should be much smaller, as suggested by their extremely low relative abundance. Using two density conditions and the confidence interval around the MVP means approximating the minimum area that state protected reserves should have to ensure viable $L$. melanocephala populations (Table 2).

\section{RESULTS}

\author{
Synonymy \\ Crotalus mutus Linnaeus, 1776 \\ Lachesis mutus Daudin, 1803 \\ Lachesis muta Picado 1931 \\ Lachesis muta stenophrys Taylor 1951
}

TABLE 2

Proportions of the total area of SINAC protected areas on the estimates of the minimum viable area (MVA) for Lachesis melanocephala

\begin{tabular}{lccccc} 
& & \multicolumn{3}{c}{ MVA $^{2}$} \\
& & Low density & \\
& & & & \\
& & Lower limit & Higher limit & Lower limit & Higher limit \\
Protected area ${ }^{1} \backslash$ MVP & Total area (Ha) & 261791.66 & 288687.51 & 26179.16 & 28868.75 \\
Humedal Terraba-Sierpe & 26779 & 0.102 & 0.093 & $1.023^{* *}$ & 0.928 \\
PN Corcovado & 42469 & 0.162 & 0.147 & $1.622^{* *}$ & $1.471^{* *}$ \\
PN Piedras Blancas & 14133 & 0.054 & 0.049 & 0.540 & 0.490 \\
PN La Amistad & 198293 & 0.758 & 0.687 & $7.574^{* *}$ & $6.869^{* *}$ \\
PN Carara & 5330 & 0.020 & 0.018 & 0.204 & 0.185 \\
PN La Cangreja & 2574 & 0.010 & 0.009 & 0.098 & 0.089 \\
Reserva Forestal Golfo Dulce & 61959 & 0.237 & 0.215 & $2.367^{* *}$ & $2.146^{* *}$ \\
RVS Carate & 141 & 0.001 & 0.000 & 0.005 & 0.005 \\
RVS Golfito & 2877 & 0.011 & 0.010 & 0.110 & 0.100 \\
RVS Pejeperro & 763 & 0.003 & 0.003 & 0.029 & 0.026 \\
RVS Preciosa Platanares & 257 & 0.001 & 0.001 & 0.010 & 0.009 \\
RVS Punta Rio Claro & 320 & 0.001 & 0.001 & 0.012 & 0.011 \\
RVS Cerro Redondo & 680 & 0.003 & 0.002 & 0.026 & 0.024 \\
RVS Finca Barú & 327 & 0.001 & 0.001 & 0.012 & 0.011 \\
RVS Hacienda Avellana & 500 & 0.002 & 0.002 & 0.019 & 0.017 \\
RVS Portalón & 449 & 0.002 & 0.002 & 0.017 & 0.016 \\
ZP Las Tablas & 19981 & 0.076 & 0.069 & 0.763 & 0.692 \\
\hline
\end{tabular}

${ }^{1}$ Only protected areas within the potential distribution of the species (see text) are shown. Protection categories include National Park (PN), Wildlife Reserve (RVS), National Wetland (H), Protective Zone (ZP).

${ }^{2}$ MVA confidence limits estimated from values of minimum viable populations for snakes from Reed et al. (2003) under two density conditions ${ }^{3}$ : low $(0.048$ individuals $/ \mathrm{Ha})$ and high $(0.48 \mathrm{ind} . / \mathrm{Ha}){ }^{*}=$ protected areas large enough to support a minimum viable population. 
Lachesis muta stenophrys Taylor 1954

Lachesis muta Vial \& Jiménez-Porras 1967

Lachesis muta stenophrys Bolaños 1982

Lachesis muta melanocephala

Solórzano \& Cerdas 1986

Lachesis muta melanocephala

Campbell \& Lamar 1989

Lachesis melanocephala

Zamudio \& Greene 1997

Lachesis melanocephala

McDiarmid, Campbell, \& Touré 1999

Lachesis melanocephala Savage 2002

Lachesis melanocephala

Fernandes, Franco \& Fernandes 2004

Lachesis melanocephala

Campbell \& Lamar 2004

Lachesis melanocephala Solórzano 2004

Description of the neotype: MZUCR23185 (Fig. 1A), is an adult male from San Juan de Rincón, Península de Osa, province of Puntarenas, along the Pacific South of Costa Rica (8.78363; -83.47683, $267 \mathrm{~m}$ elevation); collected on June 18, 2008. The dorsal coloration is a pale yellow, on which lies a pattern of 26 black rhomboidal blotches (Fig. 1D), the dorsal part of the head is uniform black (Fig. 1B), chin region is clear (Fig. 1C), and the venter is uniformly white. The measurements and scutellation are as follows: snout-vent length $(\mathrm{SVL})=$ $1890 \mathrm{~mm}$; total length $(\mathrm{TL})=2050 \mathrm{~mm}$; head length $(\mathrm{HL})=71 \mathrm{~mm}$; ventrals $=215$; cloacal plate $=$ single; divided subcaudals $=44$; dorsal scales (keeled and protuberant) at midbody $=$ 36 ; interoculars $=9-11$; supralabials $=9-9$; and infralabials $=13-13$.

Additional specimen: MZUCR-1589, and adult female from Playa Blanca, Puerto Jiménez, Península de Osa, province of Puntarenas, collected on August 1966; SVL $=1650$ mm; $\mathrm{TL}=1820 \mathrm{~mm} ; \mathrm{HL}=70 \mathrm{~mm}$; ventrals $=215$; subcaudals $=38$; dorsal scales at midbody $=$ 41 ; interoculars $=9-10$; supralabials $=8-9$; and infralabials $=13-13$.

Natural history account: Lachesis melanocephala is a terrestrial species that is mainly active at dusk or night (Solórzano, 2004), although a series of recent observations suggest that this species can be active also during the day. The species often hides among the roots of large trees, under logs, and in patches of dense vegetation mostly in primary and undisturbed secondary forests (Fig. 2A, Fig. 2B, Fig. 2C). The Black-headed Bushmaster also occupies subterranean cavities and mammal burrows, where it resides for indefinite periods. It appears to select strategic locations from which it can passively observe potential prey, a behavior characteristic of other species in the genus (Greene \& Santana, 1983; Greene, 1997; Solórzano, 2004, Diniz-Sousa, Moraes, Rodrigues-da-Silva, Oliveira, \& Caldeira, 2020). When hunting, it bites and holds on to its prey until it becomes immobilized by the venom, as is reported for other Bushmaster species (Diniz-Sousa et al., 2020). Both adults and juveniles seem to feed exclusively on small mammals, although not much information is available about their diet. Our few stomach contents and fecal analysis reveal rodents such as spiny rats (usually Heteromys desmarestianus and Proechimys semispinosus) and marsupials (family Didelphidae) as common prey items.

Its defensive behavior includes raising the head and coiling the body in a threatening posture while vibrating the tail forcefully against the ground. The Black-headed Bushmaster has a bad reputation among the species of its genus being an irascible or nervous snake, an idea that prevails even among people accustomed to its handling or capture (Ripa, 1994; Campbell \& Lamar, 2004). This reputation possibly derives from the fact that it is a species that is much more willing to lift its head and part of its body during defensive movements and escapes (Fig. 2D). Despite this, in our experience, it seldom shows a disposition to strike.

Adults of this species attain a maximum total length of $2.3 \mathrm{~m}$, with a mean of 1.9$2.0 \mathrm{~m}$ (Solórzano, 2004). Reproduction in $L$. melanocephala is seasonal, and, in captivity, copulation has been reported from October to January and hatching from May to early 


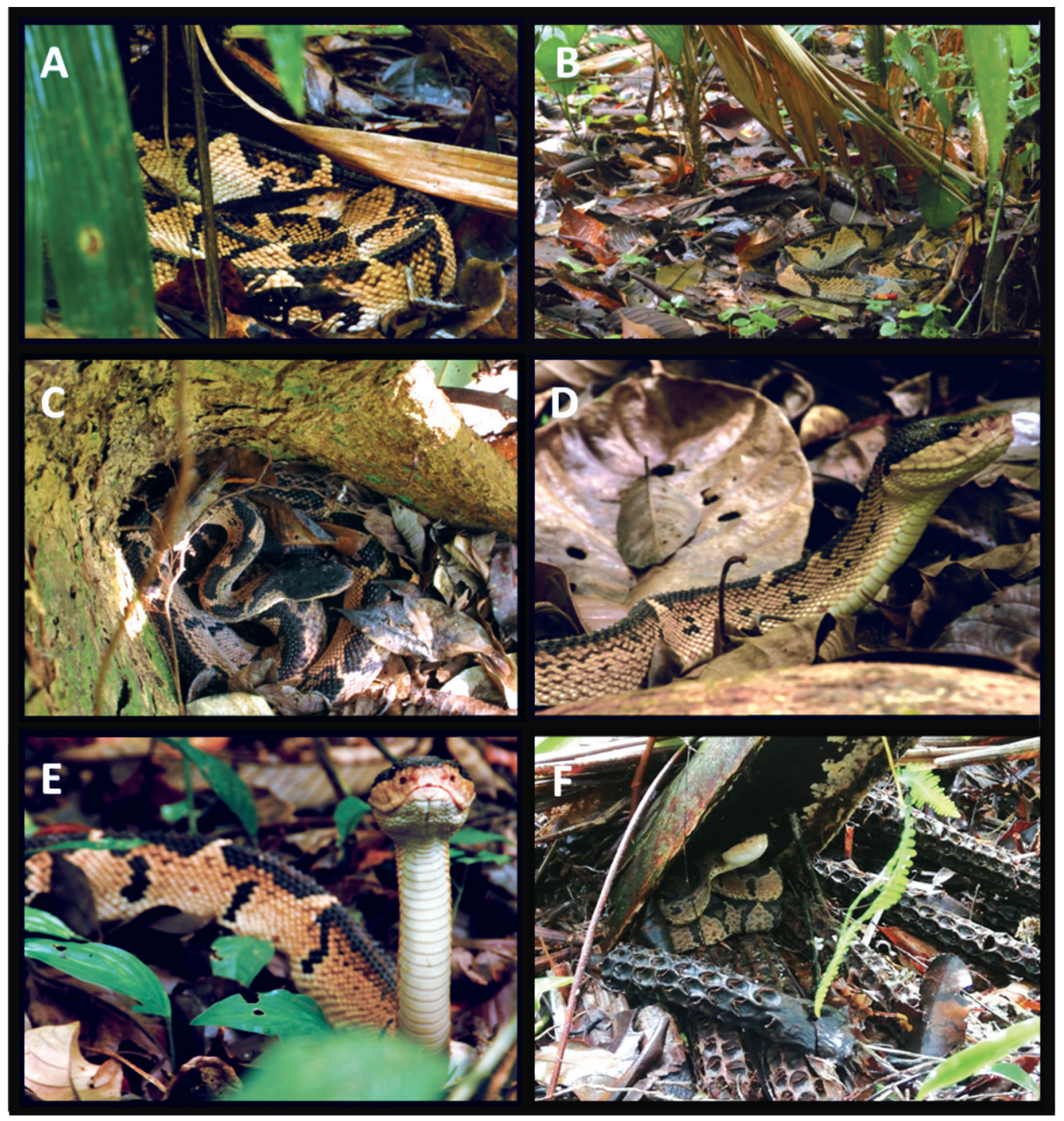

Fig. 2. Different resting sites for Lachesis melanocephala. (A, B, and F) Under palm leaves on the forest floor. (C) In tree buttress. (D, E) Periscopic displacement by raising the head. (A, B, C, D and E - Photos by Roel De Plecker; F - photo by Jacobo Mesén Sandoval).

July (De Plecker \& Dwyer, 2020). Mating includes violent movements in which the male could knock the female off the ground with his coils (Ripa, 1994, Ripa, 2004). As seen in other vipers, the male first advances toward the female and rubs his chin in her dorsum. An unusual behavior, however, is that at some point, the male turns around and, with his back on top of her, venter upwards, begins with his own back to rub the female's back forward and backward as if sawing (De Plecker \& Dwyer, 2020). This "upside-down sailing" is presumably behavior to stimulate copulation. Ripa (1994) suggests that the prominent spinal ridge observed in L. melanocephala and L. stenophrys might serve this stimulation function.

The combat between males occur during the breeding period, but there is no field description of it. However, comprehensive observations come from captivity. According 
to Ripa (1994), the combat between males is not explicit, and it is not as spectacular or violent as the behaviors described for courtship. However, De Plecker and Dwyer (2020) described how a captive male lost its life due to stress from ritual combat. Males try to coiling on top of each other, and this behavior is repeated for several nights before copulation.

In L. melanocephala, clutches are between 6-16 eggs, with an incubation period between 74-101 days in captivity (Ripa, 2004; De Plecker \& Dwyer, 2020). This period is similar to that observed for L. stenophrys (75-106 days) on the Caribbean versant (personal observation, Chacon-Gutiérrez \& Valverde, 2004). Females generally use holes in the ground or abandoned burrows to deposit their eggs. Eggs are deposited directly into the substrate within the burrow. The female protects them by wrapping them with her coils, and as she laid them, she frequently flicks her tongue over the surface of the egg, as in recognition (De Plecker \& Dwyer, 2020).

Maternal care has been suggested in all bushmaster species; L. melanocephala is no exception. The female bushmaster protects her eggs by staying with them in the burrow throughout the entire incubation period, hardly ever leaving them to drink water. Females become more restless, even more irascible, during this period; in captivity, it is still a delicate task to separate them from their egg clutches (personal observation, De Plecker \& Dwyer, 2020).

As in other vipers that protect their eggs and offspring from predators (Greene, May, Hardy, Sciturro, \& Farrell, 2002), maternal care in this species has an associated cost. Throughout the incubation period, the female fasts, this causes her to lose a significant fraction of her weight. The prolonged fast can last up to six months in total, and the reduction is estimated between 15 and $30 \%$ of body mass (Ripa, 1994). It is not clear how long it takes for females to regain their weight in the field or the effect this reproductive cost has on the population level. Still, it possibly means that the females must wait more than a year to reproduce again (see Alves, Argôlo, \& Carvalho, 2014 for a similar situation in L. muta). This hypothesis contrasts with the fact that in captivity, it is possible to breed females of this and other Lachesis species annually (Corrales, Meidinger, Rodríguez, Chacón, \& Gómez, 2014). At birth, neonates' mean total length is $44.2 \mathrm{~cm}$, with an average weight of $72.9 \mathrm{~g}$ (De Plecker \& Dwyer, 2020).

Distribution: As stated before, the distribution of this species in Costa Rica is currently restricted to the South Pacific region (Fig. 3A). However, in the past, L. melanocephala reached at least the Central Pacific of the country, as evidenced by a 1967 record from Alto Los Guarumos (elev. ca. $500 \mathrm{~m}$ ) near Puriscal, San José province (Solórzano, 2004). At that time, the natural vegetation in this region was not as altered as it is today, and forest cover was extensive. In Panama, L. melanocephala is known from a single specimen collected in Chiriquí, near the border with Costa Rica (Dwyer \& Perez, 2009); another specimen, deposited in the Museum of Vertebrate Zoology (MVZ 27321) is from an unknown Panamanian locality (Campbell \& Lamar, 2004). In this country, the Black-headed Bushmaster likely occurs in Western locations adjacent to the edge of Costa Rica, on the Pacific hillside of the Talamanca mountain range, since no significant topographic and bioclimatic barriers are present in the region.

The altitudinal distribution of L. melanocephala ranges from sea level to $1873 \mathrm{~m}$ in elevation, the highest record from Las Tablas, in the Talamanca hillside, Puntarenas province (González-Maya et al., 2014). This record exceeds the maximum reported elevation for L. stenophrys and -quite possibly- the other two bushmaster species (Campbell \& Lamar, 2004; but see Lancini, 1986 for a high elevation record for L. muta). From our records, the species is more likely to be found in the interior foothills than in the outer coastal portion of Osa Peninsula. These observations, in addition to recent reports in the foothills of Talamanca (González-Maya et al., 2014), suggest that 

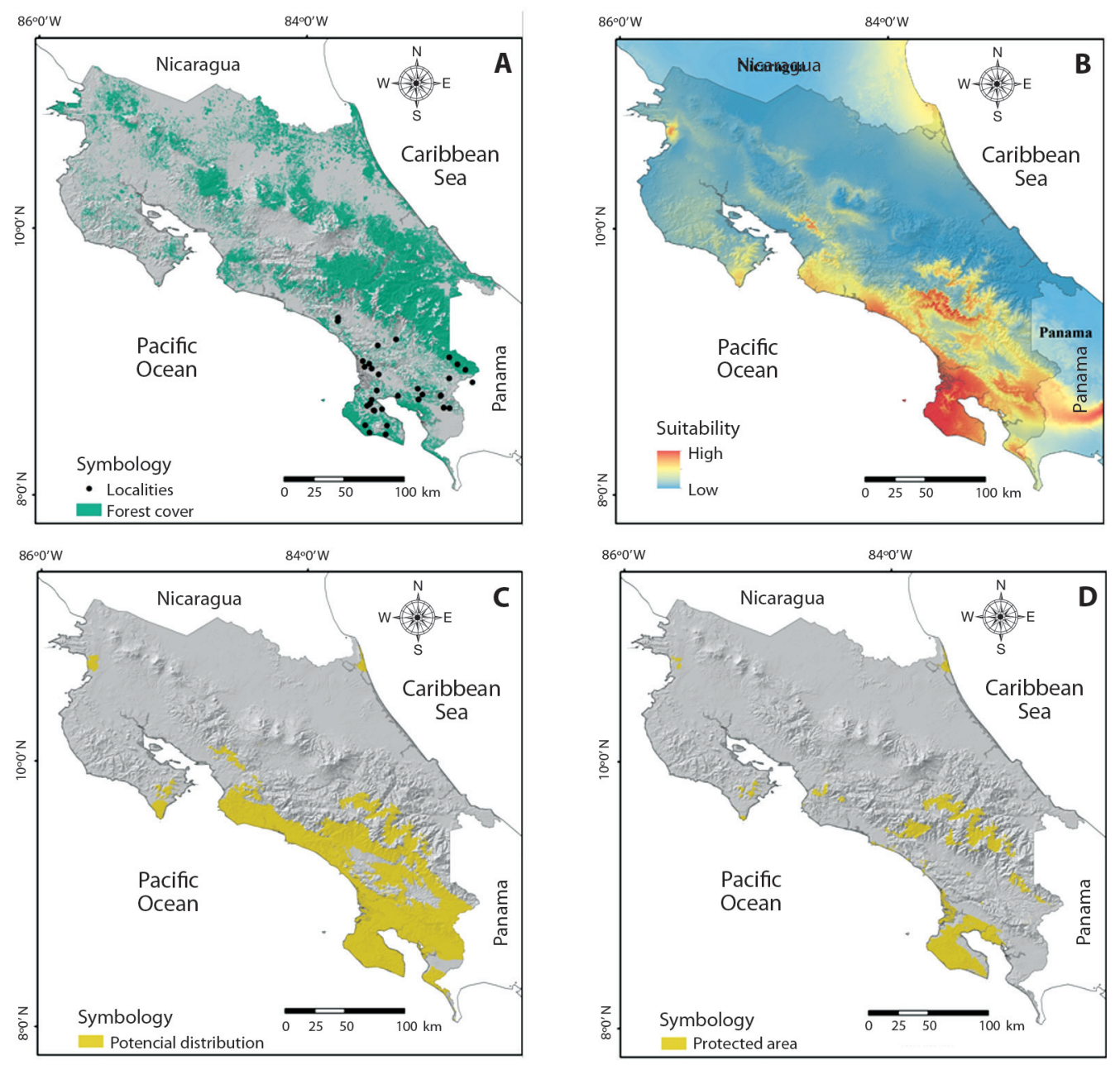

Fig. 3. A. Forest cover and locality records for L. melanocephala. B. Environmental niche model for L. melanocephala using Maxent. Localities mentioned in the text are shown. C. Potential distribution of L. melanocephala as recovered from the model. D. Protected wildlife areas included within the potential distribution of the species.

L. melanocephala possibly prefers drained slopes over flatlands.

Our potential distribution model $(\geq 50 \%$ probability of presence) indicates $10 \quad 139.24$ $\mathrm{km}^{2}$ (19.84\% of the country's territory) of habitat with favorable conditions for the Blackheaded Bushmaster to survive (i.e., vegetation cover and similar climatic conditions) (Fig. 3A, Fig. 3B). As expected, the model predicts areas where the species exists: the interior portion of the Osa Peninsula, the montane region of Coto Brus, the Talamanca foothills, and the
Fila Costeña region. It also includes the mountainous region in the Central Pacific, where the species existed in the past. Also, it retrieved some unexpected locations: Southern tip of the Nicoya Peninsula, the base of the Santa Elena Peninsula, and the Tortuguero region in the Northeast of the country (Fig. 3C). These locations might have suitable conditions for the species, but there is no evidence of occurrence there. For instance, the climatic conditions and forest cover on the Southern extreme of the Nicoya Peninsula are humid enough 
to maintain a variety of wet forest species still found there (Laurencio, 2009), but L. melanocephala has never been recorder in that area.

Within the potential distribution of the species, 18 SINAC protected areas are included, counting five national parks and nine wildliferefuges (Table 2). Approximately $2936.10 \mathrm{~km}^{2}$ of the potential distribution of L. melanocephala lies within these protected areas (Fig. 3D). This represents $29 \%$ of the species possible range, thus less than a third of the black-headed Bushmaster distribution is currently under some category of protection.

To assess if these protected areas are large enough to support viable $L$. melanocephala populations, we use two density conditions and the confidence interval around the MVP mean as depicted in Table 2. Under the high-density condition, Corcovado National Park, La Amistad International Park, and the Golfo Dulce Reserve are large enough to maintain viable populations. However, suppose the low-density condition is used, which would be more likely in rare species such as L. melanocephala. In that case, none of the protected areas is large enough to maintain a viable $L$. melanocephala population (Table 2). This exercise demonstrates that protected areas in Costa Rica might not be sufficient to guarantee viable populations of Black-headed Bushmaster.

\section{DISCUSSION}

Lachesis melanocephala is a distinctive species with a restricted distribution and a close affinity to environments with forest cover. These characteristics make it susceptible to changes in their environment and increase the risk of extinction. Below, we present aspects that we consider relevant to its conservation, based on our analysis results.

\section{Association to forested environments:}

The strong connection between bushmasters and undisturbed forest habitats has been previously noted (Greene, 1997; González-Maya et al., 2014). It is one of the most outstanding characteristics of this group of snakes. On some occasions, however, snakes of the genus Lachesis can be found in slightly more disturbed environments, such as abandoned pastureland and cocoa plantations, but always close to forest covers. From our records, L. stenophrys inhabit abandoned cacao plantations in the Northeast of Costa Rica, and L. melanocephala has been found in a small cacao plantation near Aguabuena, in the Osa Peninsula in Southern Costa Rica. Large patches of mature forest surrounded both sites. Besides, Argôlo (2004) also reports the presence of $L$. muta in cocoa plantations in the Atlantic of Brazil. Those findings are not surprising if we consider the structure of cacao plantations: although they exhibit simpler vertical structure and understory than the mature forest, their greater leaf-litter depth and the dense canopy provides similar abiotic conditions to those recorded in a forest (Lieberman, 1986). As a result, these environments can support an essential component of herpetofauna diversity in tropical regions (Argôlo, 2004; Heinen, 1992).

The reason for the close association between bushmasters and forest is not apparent: the climatic requirements (temperature, humidity) do not seem to differ from that of other species of tropical pitvipers that -in contrast- manage to survive in more altered spaces (for instances, Bothrops asper, Sasa et al., 2009). Little information is available on these animals' ecophysiological needs, on aspects of their diet selection and their spatial requirements. However, it seems that their home ranges are narrow (see Greene \& Santana, 1983 for L. stenophrys). Despite the limited information available, it appears that it is in mature forest cover that bushmasters manage to find suitable nesting sites and adequate prey.

As we have seen from our experience in keeping animals in captivity, bushmasters, in general, need humid environments with dry substrates as well as hiding places for optimal maintenance. In very wet substrates, or if adequate dens are unavailable, individuals become stressed and susceptible to infections that end up killing them. These observations are consistent with the preference -at least in the case 
of Central American bushmasters- to inhabit burrows located on slopes, which allow better drainage in the rainy places where they live.

Deforestation impact in Lachesis melanocephala: Species strongly linked to mature forest cover have the disadvantage of being susceptible to deforestation and its consequences (Sorvari \& Hakkarainen, 2007; Scott et al., 2006). Forest degradation has direct (i.e., the reduction of the potential habitat of a species) or indirect (disable other components of its ecological niche, such as availability of resources) effects on forest dwellers. In the case of L. melanocephala, the reduction of wet lowland forests and premontane and low montane forests (see below), are responsible for its local disappearance in many sites.

The pattern of deforestation in Costa Rica is connected with the country's economic development and migration history (Locher, 1997). Most deforestation occurred in the 20th century, especially in the sixties and seventies. It was led by state polices promoting the cutting of trees and the development of land for agriculture (see Sasa et al., 2010 for a summary of historical deforestation patterns and their impact in Costa Rican herpetofauna). Driven by foreign companies and the dynamics of the international marketplace, banana plantations replaced much of the forest on the South Pacific lowlands. By the late seventies, Lowland Moist Forest in this region was limited mostly to the Osa Peninsula. Up North, in the foothills of Talamanca, the colonization process that began in the 1950s with the arrival of Italian settlers for agricultural production in the Java River Valley evolved into a critical coffee industry that continues today.

The impact of the Coto Brus mountain region's development was the substantial loss of premontane and low montane forests (Sansoneti, 1995; Quesada-Román \& Díaz-Bolaños, 2019), today restricted to the protected $\mathrm{La}$ Amistad International Park.

The deforestation rate declined by the mid-eighties (Garcia et al., 2005), allowing the forest in some areas of the country to recover, although much of the cover that remains is heavily fragmented (Sanchez-Azofeifa et al., 2001; Garcia et al., 2005). Forest fragmentation affects populations and ecological functionality of the system and is one of the leading causes of biodiversity reduction. Thinning of vertebrate species, known as defaunation (Dirzo \& Miranda, 1991), is the norm in many forest fragments. The decline in abundance and occurrence of animals in a community can have cascading effects, affecting the dynamics of other animals and plants (Kurten, 2013). Although we do not have supporting data, it is easy to imagine that a decline in small mammals that dig burrows (agoutis, pacas, armadillos) by hunting or habitat fragmentation may severely limit refuge availability for bushmasters.

Anecdotal evidence supports the marked decline in bushmasters' relative abundance in Costa Rica, even in forested areas. During the first three years of its foundation in 1970, the Clodomiro Picado Institute (University of Costa Rica) received close to 300 individuals L. stenophrys from the country's Caribbean region (Taylor, Flores, Flores, \& Bolaños, 1973). Today, the number of records is less than one every two years. At La Selva Biological Station, one of the best-known tropical forests in the Neotropics (McDade \& Hartshorn, 1994), the species went from being seen with some frequency in the eighties and nineties (Greene \& Santana, 1983; Greene, 1997; Guyer \& Donnelly, 2004), to be infrequent at the turn of the century. The last L. stenophrys reported for this place date from 2003; ever since, it has not been observed again, despite our intensive search there in the last 17 years.

Similarly, L. melanocephala is now an extremely rare snake through what is left of its range. With the rise of ecotourism, the forested areas of the Southern Pacific of the country have become centers of attraction (Hunt, Durham, Driscoll, \& Honey, 2015), promoting not only more people in the bushmaster habitat but also people who are actively looking for animals to display them. Despite this increase in the search effort, encounters with the Black-headed 
Bushmaster are very few and sporadic, limited to only but a few locations.

\section{Black-headed Bushmaster conserva-} tion: Our analyses suggest that the protected areas along the distribution of L. melanocephala may not be sufficient to guarantee viable populations. Consequently, we need to complement conservation strategies based on the protection of areas, as traditionally carried out by the SINAC, with other conservation strategies. Two approaches that could improve the species' chances of survival are ex-situ conservation (through captive breeding programs) and the establishment of a robust environmental education program (Morgan, 1992) specifically aimed at protecting the Black-headed Bushmaster. We consider these strategies to be explored or internalized in SINAC's work plans if the conservation objectives of species that do not have much chance of achieving sustainable populations in the environment are met.

Ex-situ conservation of threatened snakes is a strategy with a long tradition in North America and European countries (Barker \& Barker, 2014; Odum \& Reinert, 2015). Still, it has not received the same attention in tropical countries. In Costa Rica, for example, 21 out of 33 reptile centers maintain bushmasters, mainly L. stenophrys (Arias-Ortega, BonillaMurillo, \& Sasa, 2016). However, only two of them attempt to breed these snakes, and only in one, Reptilanda, the captive reproduction of $L$. melanocephala has been successful (De Pleck \& Dwyer, 2020). Promoting the production of L. melanocephala in this and other centers should be considered an essential step toward its conservation.

On the other hand, educational projects focused on snake species are currently nonexistent in the country, although such programs have been implemented in other regions (Morgan \& Gramann, 1989; Ballouard, Provost, Barré, \& Bonnet, 2012). However, there is an experience to raise public awareness about the conservation of other reptiles, such as sea turtles, through education programs that focus on them (Sasa et al., 2010). As a first step in establishing an educational program of this nature aimed at protecting a venomous snake, it would be necessary to determine if it can be seen as a flagship species, attracting the target audience's interest.

The Black-headed Bushmaster as a flagship species: Surrogate species is an essential complementary strategy in biodiversity conservation schemes at different scales (BowenJones \& Entwistle, 2002; Schlegel \& Rupf, 2010). Some species are attractive because they can be used as an index of environmental attributes that are difficult, inconvenient, or expensive to measure. They can be used as a symbol that gives identity to a group. The general idea is that if resources can be allocated to protect a few attractive species, other species could also be protected. Flagship species should attract public interest in a way that no other species does. Often, the criteria used to select emblematic species are based on aesthetic condition, state of conservation, or if the species is a cultural or an indicator species (Bowen-Jones \& Entwistle, 2002). According to Jepson \& Barua (2015), flagship species must have characteristics that allow the public to form coherent associations with concepts located in pre-existing cultural settings. For example, species with traits that are part of the networks that incorporate human fears, such as being venomous, will be less likely to become emblematic species due to the restrictions they have to align with the frameworks that incorporate collective aspirations (Jepson $\&$ Barua, 2015). This prediction would assume that a venomous snake feared due to its large size and the potency of its venom (Jorge et al., 1997, Madrigal et al., 2012, Diniz-Sousa et al., 2020), possibly has little chance of becoming a successful iconic species.

However, attitudes about those same snake species may change in a different context (Bowen-Jones \& Entwistle, 2002), for example, if the associations are perceived in a positive cultural setting. Snakes in the genus Lachesis are considered as indicators of pristine or mature humid forests, which have led 
international and local groups to suggest their potential as flagship species (REF). Before we do so, it is necessary to create a link between bushmasters and the general public.

The scarcity of Black-headed Bushmasters and the fact that they are associated with mature forest environments in a restricted region in Southern Costa Rica are already making them enigmatic animals that attract ecotourism. In the Osa Peninsula, the search and observation of this species are promoted. The same is happening on the Caribbean side of the country with its sister species. The unexpected attraction that bushmasters generate can catapult them to the public; that could adopt them as a local emblematic species. A similar situation is already happening with the scarlet macaw and the jaguar in the region. The conservation approach of traditionally negative groups, such as snakes, must include a diagnosis of the affinity generated in the target audience and, from there, design better awareness campaigns. Therefore, we highlight the need to approach bushmaster conservation from an inclusive perspective: promote awareness of the importance of this and other species of snakes and their value to society, enhance partnerships with different stakeholders, and empower communities to act in their protection. Only then will the magnificent Black-headed Bushmaster have a chance to survive.

Ethical statement: authors declare that they all agree with this publication and made significant contributions; that there is no conflict of interest of any kind; and that we followed all pertinent ethical and legal procedures and requirements. All financial sources are fully and clearly stated in the acknowledgements section. A signed document has been filed in the journal archives.

\section{ACKNOWLEDGMENTS}

We thank Louis W. Porras, William W. Lamar, Quetzal Dwyer and Gerardo Chaves (Cachí) for their criticisms and suggestions for this manuscript and for providing us with related data. Marcelo Carvajal shared his experiences in the field with this species. We are indebted to Roel De Plecker and Jacobo Mesén Sandoval for allowing us to use some of his photographs and to Sofía Granados for performing the spatial analyzes.

\section{RESUMEN}

Redescripción de la serpiente Lachesis melanocephala (Squamata: Viperidae): designación del neotipo, historia natural y estado de conservación. Introducción: La serpiente Plato Negro (Lachesis melanocephala) es una especie venenosa de gran tamaño, endémica de los bosques lluviosos del Pacífico sur y suroeste de Costa Rica y el extremo oeste de Panamá. Objetivo: Se asigna un neotipo para la especie debido a la pérdida del holotipo original y se presentan datos actualizados de su distribución geográfica, historia natural y estado de conservación. Métodos: Para determinar el estado de conservación de L. melanocephala, reconstruimos su distribución potencial utilizando los registros de localidad de la especie y el análisis de modelado de distribución implementado en MaxEnt. En función de la distribución potencial de la especie, evaluamos la pérdida de su hábitat original y calculamos el porcentaje de su área de distribución que actualmente está protegida por el sistema de áreas protegidas del país. Resultados: La distribución potencial de la especie se estimó en 10139 $\mathrm{km}^{2}$, incluyendo áreas donde la especie se encuentra actualmente y áreas históricas donde la especie se ha registrado, pero se considera localmente extinta. Cerca del $29 \%$ de esa distribución potencial se traslapa con áreas silvestres protegidas, por lo que menos de una tercera parte de la distribución potencial de la especie está bajo protección. Conclusiones: La degradación acelerada de su hábitat y la disminución evidente de sus poblaciones durante la última década señalan la necesidad de tomar medidas urgentes de protección para evitar el riesgo de extinción a corto plazo o mediano plazo.

Palabras clave: víboras neotropicales; conservación de serpientes; modelo de distribución de especies.

\section{REFERENCES}

Alves, F.Q., Argôlo, A.J., \& Carvalho, G.C. (2014). Reproductive biology of the bushmaster Lachesis muta (Serpentes: Viperidae) in the Brazilian Atlantic Forest. Phyllomedusa, 13(2), 99-109.

Arias-Ortega, J., Bonilla-Murillo, F., \& Sasa, M. (2016). Desarrollo de la herpetocultura en Costa Rica: Situación actual de herpetarios y manejo ex situ de reptiles y anfibios. Revista de Ciencias Ambientales, $50(1), 1-23$. 
Argôlo, A.J.S. (2004). As serpentes dos cacauais do sudeste da Bahia. Bahia, Brasil: Editus Editora da UESC.

Ballouard, J.M., Provost, G., Barré, D., \& Bonnet, X. (2012). Influence of a field trip on the attitude of schoolchildren toward unpopular organisms: an experience with snakes. Journal of Herpetology, 46(3), 423-428.

Barker, D.G., \& Barker, T.M. (2014). The invisible ark: in defense of captivity. Virginia, USA: VPI Library.

Bolaños, R., Muñoz, G., \& Cerdas, L. (1978). Toxicidad, neutralización e inmunoelectroforesis de los venenos de Lachesis muta de Costa Rica y Colombia. Toxicon, 16(3), 295-300.

Bolaños, R. (1982). Las serpientes venenosas de Centroamérica y el problema del ofidismo. Primera parte. Aspectos zoológicos, epidemiológicos y biomédicos. Revista Costarricense de Ciencias Médicas, $3(2), 165-184$.

Bowen-Jones, E., \& Entwistle, A. (2002). Identifying appropriate flagship species: the importance of culture and local contexts. Oryx, 36(2), 189-195. DOI: $10.1017 / \mathrm{S} 0030605302000261$

Campbell, J.A., \& Lamar, W.W. (1989). The Venomous Reptiles of Latin America. Ithaca, USA: Cornell University Press.

Campbell, J.A., \& Lamar, W.W. (2004). The Venomous Reptiles of the Western Hemisphere. Ithaca, USA: Cornell University Press.

Chacón-Gutiérrez, D., \& Valverde, R. (2004). Lachesis stenophrys (Bushmaster). Lachesis stenophrys (cascabela muda). Herpetological Review, 35(1), 68.

Corrales, G., Meidinger, R., Rodríguez, S., Chacón, D., \& Gómez, A. (2014). Reproduction in captivity of the Central American bushmaster (Lachesis stenophrys, Serpentes: Viperidae), in Costa Rica. Cuadernos de Herpetología, 28(2), 137-139.

Daudin, F.M. (1803). Histoire naturelle generale et particuliere des reptiles (Vol. 8). Paris, France: F. Dufart.

De Plecker, R., \& Dwyer, Q. (2020). First Breeding of the Black-headed Bushmaster (Lachesis melanocephala) in Costa Rica. Herpetological Review, 51(1), 57-64.

Diniz-Sousa, R., Moraes, J.D.N., Rodrigues da Silva, T.M., Oliveira, C.S., \& Caldeira, C.A. (2020). A brief review on the natural history, venomics and the medical importance of bushmaster (Lachesis) pit viper snakes. Toxicon, $X, 7,100053$.

Dirzo, R., \& Miranda, A. (1991). Altered patterns of herbivory and diversity in the forest understory: a case study of the possible consequences of contemporary defaunation. In P.W. Price, T.M. Lewinsohn, G.W. Fernandes, \& W.W. Benson (Eds.),
Plant-animal interactions: evolutionary ecology in tropical and temperate regions (pp. 273-287). New York, USA: Wiley.

Dwyer, Q., \& Perez, M. (2009). Lachesis melanocephala. Herpetological Review, 40(1), 114.

Fernandes, S. (2001). Revisão sistemática do gênero Lachesis Daudin, 1803 (Serpentes: Viperidae: Crotalinae) (Master Thesis). Universidade Federal do Rio de Janeiro, Brasil.

Fernandes, D.S., Franco, F.L., \& Fernández, R. (2004). Systematic revision of the genus Lachesis Daudin 1803 (Serpentes: Viperidae). Herpetologica, 60(2), 245-260.

García, R., Obando, V., \& Murillo, K. (2005). Gestión del patrimonio. In Undecimo Informe sobre el Estado de la Nación en Desarrollo Humano Sostenible (pp. 1-38). San José, Costa Rica: Programa de Estado de la Nación.

Gilpin, M.E., \& Soulé, M.E. (1986). Minimum viable populations: the processes of species extinctions. In M.E. Soulé (Ed.), Conservation biology: the science of scarcity and diversity (pp. 13-34). Massachusetts, USA: Sinauer Associates.

González-Maya, J.F., Castañeda, F., González, R., Pacheco, J., \& Ceballos, R. (2014). Distribution, range extension and conservation of the endemic Blackheaded Bushmaster (Lachesis melanocepahala) in Costa Rica and Panama. Herpetological Conservation and Biology, 9(2), 369-377.

Greene, H.W. (1997). Snakes: The Evolution of Mystery in Nature. California, USA: University of California Press.

Greene, H.W., \&. Santana, M.A. (1983). Field studies of hunting behavior by bushmasters. American Zoologist, 23, 897 .

Greene, H.W., May, P.G., Hardy, D.L., Sciturro, J.M., \& Farrell, T.M. (2002). Parental behavior by vipers. Biology of the Vipers, 179-205.

Guyer, C., \& Donnelly, M.A. (2004). Amphibians and reptiles of La Selva, Costa Rica, and the Caribbean Slope: a comprehensive guide. California, USA: University of California Press.

Heinen, J.T. (1992). Comparisons of the leaf litter herpetofauna in abandoned cacao plantations and primary rain forest in Costa Rica: some implications for faunal restoration. Biotropica, 24(3), 431-439.

Hijmans, R.J., Cameron, S.E., Parra, J.L., Jones, P.G., \& Jarvis, A. (2005). Very high resolution interpolated climate surfaces for global land areas. International Journal of Climatology: A Journal of the Royal Meteorological Society, 25(15), 1965-1978. 
Hunt, C.A., Durham, W.H., Driscoll, L., \& Honey, M. (2015). Can ecotourism deliver real economic, social, and environmental benefits? A study of the Osa Peninsula, Costa Rica. Journal of Sustainable Tourism, 23(3), 339-357.

IUCN. (2012). IUCN Red List Categories and Criteria (Version 3.1). Gland, Switzerland: International Union for Conservation of Nature.

Jepson, P., \& Barua, M. (2015). A theory of flagship species action. Conservation and Society, 13(1), 95-104.

Jorge, M.T., Sano-Martins, I.S., Tomy, S.C., Castro, S.C., Ferrari, R.A., Ribeiro, L.A., \& Warrell, D.A. (1997). Snakebite by the Bushmaster (Lachesis muta) in Brazil: case report and review of the literature. Toxicon, $35(4), 545-554$.

Kurten, E.L. (2013). Cascading effects of contemporaneous defaunation on tropical forest communities. Biological Conservation, 163, 22-32.

Laurencio, D. (2009). Amphibians and reptiles from Reserva Natural Absoluta Cabo Blanco, province of Puntarenas, Costa Rica. Check list, 5(3), 446-459.

Lancini, V.A. (1986). Serpientes de Venezuela (2nd ed.) Caracas, Venezuela: Talleres Graficas Armitaño.

Lieberman, S.S. (1986). Ecology of the leaf litter herpetofauna of a Neotropical rain forest: La Selva, Costa Rica. Acta Zoologica Mexicana, 13(15), 1-72.

Linnaeus, C. (1776). Systema naturae per regna tria naturae. secundum classes, ordines, genera, species cum, characteribus, differentiis, synonymis, locis (12th ed.). Stockholm, Sweden: Laurentii Salvii.

Locher, U. (1997). Migraciones y cambios medioambientales en Costa Rica desde 1927. In A.P.L. RoseroBixby, \& A.B. Mendez (Eds.), De los Mayas a la Planificación Familiar: Demografia del Istmo (pp. 135-156). San José, Costa Rica: Editorial Universidad de Costa Rica.

Madrigal, M., Sanz, L., Flores-Díaz, M., Sasa, M., Núñez, V., Alape-Girón, A., \& Calvete, J.J. (2012). Snake venomics across genus Lachesis. Ontogenetic changes in the venom composition of Lachesis stenophrys and comparative proteomics of the venoms of adult Lachesis melanocephala and Lachesis acrochorda. Journal of Proteomics, 77, 280-297.

McDade, L.A. \& Hartshorn, G.S. (1994). La Selva: Ecology and natural history of a Neotropical rain forest. Chicago, USA: The University of Chicago Press.

McDiarmid, R.W., Campbell, J.A., \& Touré, T.A. (1999). Snake Species of the World: A Taxonomic and Geographic Reference. Washington D.C., USA: The Herpetologists' League.
Morgan, J.M. (1992). A theoretical basis for evaluating wildlife-related education programs. The American Biology Teacher, 54(3), 153-157.

Morgan, J.M., \& Gramann, J.H. (1989). Predicting effectiveness of wildlife education programs: A study of students' attitudes and knowledge toward snakes. Wildlife Society Bulletin (1973-2006), 17(4), 501-509.

Muscarella, R., Galante, P.J., Soley-Guardia, M., Boria, R.A., Kass, J.M., Uriarte, M., \& Anderson, R.P. (2014). ENM eval: An R package for conducting spatially independent evaluations and estimating optimal model complexity for Maxent ecological niche models. Methods in Ecology and Evolution, 5(11), 1198-1205.

Odum, R.A., \& Reinert, H.K. (2015). The Aruba Island rattlesnake Crotalus unicolor Species Survival Plan: a case history in ex-situ and in-situ conservation. International Zoo Yearbook, 49(1), 104-112.

Ortiz-Malavasi, E. (2014). Atlas de Costa Rica 2014. Cartago, Costa Rica: Instituto Tecnológico de Costa Rica.

Picado, C. (1931). Serpientes venenosas de Costa Rica. Sus venenos. Seroterapia anti-ofidica. San José, Costa Rica: Imprenta Alsina.

Phillips, S.J., Anderson, R.P., \& Schapire, R.E. (2006). Maximum entropy modeling of species geographic distributions. Ecological Modelling, 190(3-4), 231-259.

Quesada-Román, A., \& Díaz-Bolaños, R. (2019). Impactos ambientales de la colonización agrícola en Coto Brus, Costa Rica (1940-2018). Revista Geográfica de América Central, 2(63), 215-247.

Radosavljevic, A., \& Anderson, R.P. (2014). Making better Maxent models of species distributions: complexity, overfitting and evaluation. Journal of Biogeography, 41(4), 629-643.

Reed, D.H., O’Grady, J.J., Brook, B.W., Ballau, J.D., \& Frankham, R. (2003). Estimates of minimum viable population sizes for vertebrates and factors influencing those estimates. Biological Conservation, 113, 23-34.

Ripa, D. (1994). The reproduction of the Central American bushmaster (Lachesis muta stenophrys) and the blackheaded bushmaster (Lachesis muta melanocephala) for the first time in captivity. Bulletin of the Chicago Herpetological Society, 29, 165-183.

Ripa, D. (2004). The Bushmasters (Genus Lachelis Daudin, 1803): Morphology in Evolution and Behaviour. Wilmington, USA: Ripa Ecologica.

Sanchez-Azofeifa, G.A, Harriss, R.C., \& Skole, D.L. (2001). Deforestation in Costa Rica: a quantitative analysis using remote sensing imagery. Biotropica, $33,378-384$. 
Sansonetti, V. (1995). Quemé mis naves en estas montañas: la colonización de la altiplanicie de Coto Brus y la fundación de San Vito de Java. San José, Costa Rica: Jiménez \& Tanzi.

Sasa, M., Wasko, D., \& Lamar, W.W. (2009). Natural history of the terciopelo Bothrops asper in Costa Rica. Toxicon, 54, 904-922.

Sasa, M., Chaves, G., \& Porras, L.W. (2010). The Costa Rican Herpetofauna: Conservation Status and Future Perspectives. In L.D. Wilson, J.H. Townsend, \& J.D. Johnson (Eds.), Conservation of Mesoamerican Amphibians and Reptiles (pp. 511-604). Utah, USA: Eagle Mountain Publishing, LC.

Savage, J.M. (2002). Amphibians and Reptiles of Costa Rica: A Herpetofauna between Two Continents between Two Seas. Chicago, USA: The University of Chicago Press.

Scott, D.M., Brown, D., Mahood, S., Denton, B., Silburn, A., \& Rakotondraparany, F. (2006). The impacts of forest clearance on lizard, small mammal and bird communities in the arid spiny forest, Southern Madagascar. Biological Conservation, 127(1), 72-87.

Schlegel, J., \& Rupf, R. (2010). Attitudes towards potential animal flagship species in nature conservation: a survey among students of different educational institutions. Journal for Nature Conservation, 18(4), 278-290.

SINAC. (2020). Sistema Nacional de Áreas de Conservación. Retrieved from http/www.sinac.go.cr.

Solórzano, A. (2004). Serpientes de Costa Rica: Distribución, taxonomía e historia natural. Heredia, Costa Rica: Instituto Nacional de Biodiversidad (INBio).
Solórzano, A., \& Cerdas, L. (1986). A new subspecies of the bushmaster, Lachesis muta, from southeastern Costa Rica. Journal of Herpetology, 20(3), 463-466.

Sorvari, J., \& Hakkarainen, H. (2007). Wood ants are wood ants: deforestation causes population declines in the polydomous wood ant Formica aquilonia. Ecological Entomology, 32(6), 707-711.

Taylor, E.H. (1951). A brief review of the snakes of Costa Rica. The University of Kansas Science Bulletin, 34, 1-188.

Taylor, E.H. (1954). Further studies on the serpents of Costa Rica. The University of Kansas Science Bulletin, 36, 673-800.

Taylor, R.T., Flores, A., Flores, G., \& Bolaños, R. (1973). Geographical distribution of Viperidae, Elapidae and Hydrophidae in Costa Rica. Revista de Biología Tropical, 21(2), 383-397.

Vial, J.L., \& Jiménez-Porras, J.M. (1967). The ecogeography of the Bushmaster, Lachesis muta, in Central America. American Midland Naturalist, $78(1), 182-187$.

Wallach, V., Williams, K.L., \& Boundy, J. (2014). Snakes of the World: A Catalogue of Living and Extinct Species. Florida, USA: CRC Press.

WorldClim. (2020). Global climate and weather data (version 1.4). Retrieved from http://www.worldclim. org/bioclim

Zamudio, K.R., \& Greene, H.W. (1997). Phylogeography of the bushmaster (Lachesis muta: Viperidae): implications for Neotropical biogeography, systematics, and conservation. Biological Journal of the Linnean Society, 62, 421-442. 